\title{
Transgênicos, letramento científico e cidadania
}

\section{RESUMO}

Beatriz Ceschim

beatriz ceschim@hotmail.com 0000-0003-3822-7553

Universidade Estadual Paulista "Júlio de Mesquita Filho" - UNESP

Campus Bauru/Faculdade de Ciências - Programa de Pós-

Graduação em Educação para

Ciência

Thais Benetti de Oliveira thaisbbbp@hotmail.com 0000-0003-0145-2888

Universidade Sagrado Coração (USC-Bauru)

\begin{abstract}
Tendo em vista a formação para a ação cidadã, para que a participação pública em discussões tecnológicas e científicas e na tomada de decisões de dimensões locais ou globais seja exequível, a sociedade necessita da formação científica que permita a compreensão de problemas e de possíveis intervenções. Admitindo as deficiências formativas que o ensino restrito à dimensão conceitual pode desempenhar quando o currículo escolar não abrange habilidades que permitiriam ao estudante desempenhar o papel de cidadão, são engendradas nesse artigo considerações acerca do ensino referente aos transgênicos. A problemática contemporânea envolvida em torno da biotecnologia de transgênicos é explorada, tendo em vista a caracterização da transgenia como um conteúdo sociocientífico. É proposta uma estratégia didática de sessões de debate entre estudantes para aplicação em espaços formais de ensino. A finalidade dessa atividade proposta é a viabilização do letramento científico dos educandos por meio de um "ensaio" de democracia participativa, visando ao preparo para o engajamento científico que proporciona a perspectiva de diálogo entre especialistas e a sociedade.
\end{abstract}

PALAVRAS-CHAVE: Transgênicos. Letramento científico. Formação para cidadania. Engajamento científico. 


\section{INTRODUÇÃO}

A prática democrática que pretende atender às necessidades coletivas requer inclusão de ações de consulta pública e de engajamento da sociedade em instâncias decisórias referentes a questões tecnológicas e científicas. Para concretização de tais ações, a sociedade que intenta participação precisa ter domínio de saberes e habilidades que propiciem o entendimento de problemáticas multidimensionais que envolvem ciência, tecnologia, questões éticas, interesses políticos e que envolvem riscos e benefícios. Além do entendimento das problemáticas, a sociedade também precisa mobilizar saberes e habilidades para realizar intervenções, no sentido de transformar a realidade para o bem comum. Formar estudantes para compreensão e transformação da realidade é objetivo da própria escolarização da Educação Básica (Vasconcellos, 2002).

Porém, é preciso questionar a formação dos estudantes durante a Educação Básica no que diz respeito às necessidades de se extrapolar o conteúdo conceitual como objeto de ensino para incluir também habilidades científicas, tais como lidar com informações disponíveis de modo a atribuir adequadamente significados para questões sociocientíficas contemporâneas e aplicar o conhecimento científico em intervenções de transformação da realidade.

Também é preciso questionar se a democracia, como prática social humana, se torna objeto de ensino em alguma das fases da educação básica. Ou seja, a escola tem ensinado o exercício da democracia para estudantes que irão constituir a sociedade adulta do futuro? Se a escola não propicia tal aprendizagem, onde, como e quando os estudantes terão oportunidades para atuarem como cidadãos? A formação da Educação Básica ensina o estudante a lidar, por exemplo, com uma situação na qual seja necessário o indivíduo ou um grupo confrontar conjunturas injustas, incoerentes ou ineficientes e que requerem mudanças? Será que diante de uma questão sociocientífica local ou global, o estudante egresso do Ensino Médio é capaz de formar uma opinião esclarecida que lhe permita participar com seu ponto de vista e com sugestões?

Se a escola já enfrenta desafios para o ensino de conteúdos conceituais, também haverá obstáculos para o enfrentamento do objetivo de formar estudantes para lidar com questões sociocientíficas. A própria formação dos professores de ciências - caracterizada pela fragmentação disciplinar que dificilmente integra aspectos sociais, políticos e éticos adjacentes à ciência e tecnologia - é um obstáculo a ser transposto (PEREZ; CARVALHO, 2012). No que diz respeito à dinâmica escolar, também há dificuldades apontadas por professores, como a influência do currículo tradicional de ciências, que restringe a prática dos professores a metodologias e teorias não inovadoras (ibid.). Professores apontam que sentem medo de enfrentar conflitos com os diretores de escolas, que controlam as discussões do currículo; além disso, professores vivenciam restrições impostas pelo excesso de conteúdo conceitual e por sistemas de avaliação que não valorizam a aprendizagem necessária para a formação voltada às questões sociocientíficas (REIS; GALVÃO, 2008).

Para viabilizar a transposição de alguns dos obstáculos, é preciso minimizar o distanciamento entre a academia e a escola (entre pesquisadores e professores), pois esse afastamento configura um descompasso entre os resultados das 
inovadoras, balizadas em referenciais teóricos sólidos e atuais (DELIZOICOV; ANGOTTI; PERNAMBUCO, 2011).

É balizada nessa lógica que, cabe às universidades e às instituições de pesquisa, o papel de investigar e desenvolver um quadro teórico e material que dê suporte ao trabalho nas escolas, principalmente em temas como as questões sociocientíficas, contribuindo diretamente com sua aplicação - o que corresponderia aos trabalhos do foco temático analisado, ao avaliarem estratégias de ensino (KRASILCHIK, 1987).

Assim, a presente discussão teórica está centrada na biotecnologia de transgênicos - organismos que adquiriram por meios artificiais um ou mais genes de outra espécie, ou seja, organismos que tenham sido modificados para expressar um gene de outra espécie (REECE et al., 2015). Trata-se de um tema atual e de relevância fundamental no que diz respeito à formação para ação cidadã. A transgenia é uma controvérsia científica que pode ser entendida como uma questão sociocientífica e, portanto, pode ser alvo de estratégias de ensino na educação formal. No Brasil, a biotecnologia da transgenia é muito empregada e gradativamente as aplicações alcançam maior amplitude, ainda que a população aparentemente rejeite ou questione tais aplicações - o que justifica a escolha da temática para a presente discussão.

Os transgênicos representam uma temática que é objeto de ensino da Educação Básica, e que requer extrapolar (considerando finalidades formativas da escolarização) conteúdos conceituais - por ser um conteúdo que permite o desenvolvimento de habilidades de exploração e análise de informações fragmentadas e parciais, bem como de habilidade de tomar decisões esclarecidas fundamentadas em conceitos científicos e em princípios éticos.

Sendo assim, esse artigo tem o objetivo de engendrar considerações acerca do ensino referente aos transgênicos, e inclui a proposição de uma estratégia didática de sessões de debate entre alunos para aplicação durante a escolarização. Por se tratar de uma proposta de atividade em espaço formal de ensino, a finalidade da atividade é o letramento científico dos educandos, visando ao preparo para o engajamento científico que proporciona a perspectiva de diálogo entre especialistas e a sociedade.

Por meio de uma breve análise da opinião pública referente aos transgênicos em alguns países e de modelos de participação pública, será realizada uma discussão da importância da educação científica como meio para introduzir novos papeis da sociedade em esferas públicas de processos decisórios, e, acerca de como estratégias de ensino de questões sociocientíficas por meio de debates em sala de aula podem ter um papel importante na educação científica no que é referente à formação para ação cidadã. Tal relação entre a educação científica e a formação cidadã será explorada na próxima seção.

\section{QUESTÕES SOCIOCIENTÍFICAS, LETRAMENTO CIENTÍFICO, CIDADANIA E NATUREZA DA CIÊNCIA}

Embora o Ensino de Ciências possa objetivar a viabilização de um maior apoio inovações tecnológicas, nem sempre maiores níveis de conhecimento estão relacionados com maior aceitação (PRIEST, 2013). Sendo assim, a principal razão 
para aumentar o conhecimento acerca da ciência é melhorar a prática democrática de modo que as pessoas possam tomar decisões individuais e coletivas no que diz respeito a assuntos relacionados à ciência e tecnologia (ibid.).

A educação formal, além de proporcionar a aprendizagem de conceitos científicos, precisa preparar o aluno para o exercício da cidadania por meio de habilidades com as quais explorariam questões científicas apresentadas no futuro, uma vez que os conceitos científicos podem passar constantemente por mudanças (RATCLIFFE; GRACE, 2003). Há limitações significativas em atribuir à educação científica apenas o papel de fornecimento do conhecimento e da compreensão dos conceitos. Segundo Ratcliffe e Grace (2003), estudos realizados com adultos mostram que muitos podem buscar um conhecimento detalhado e complexo de ciência quando estão imersos em determinado problema ou questão, à revelia desse conhecimento ter sido abordado em um espaço formal de ensino. Sendo assim, é possível afirmar que um excessivo ensino de conteúdo científico conceitual pela escola seria desnecessário.

Formar para a cidadania é formar pessoas que têm compreensão do próprio papel como cidadão do mundo; que respeitam e valorizam a diversidade; têm um entendimento de como o mundo funciona economicamente, politicamente, culturalmente, socialmente, tecnologicamente e ambientalmente; que são contrárias à injustiça social; que participam e contribuem com a comunidade de vários modos em nível local e global; que estão dispostas a agir para tornar o mundo um lugar mais igualitário e sustentável; e que assumem as responsabilidades de suas ações (RATCLIFFE; GRACE, 2003).

Ratcliffe e Grace (2003) consideram que apesar de serem distintas as formas como se pode dar significado à educação para cidadania, é defendida a ideia de que os cidadãos precisam de conhecimento e compreensão do sistema social, jurídico e político em que vivem e operam. Eles precisam de habilidades e aptidões para fazer uso desse conhecimento e precisam ser dotados de valores para que o uso de tais conhecimentos e habilidades seja direcionado a fins benéficos.

Questões sociocientíficas podem ser determinantes na formação de opinião e tomada de decisão em níveis pessoais e sociais, sendo com frequência reportadas pela mídia, normalmente tratadas por meio de informações incompletas devido à apresentação de evidências científicas conflitantes ou insuficientes; podem incluir dimensões locais, nacionais e globais de quadros políticos e sociais e envolvem algumas análises de custo e benefício, nas quais riscos interagem com valores. Podem envolver considerações acerca de desenvolvimentos sustentáveis e envolvem raciocínios éticos e de valores morais (RATCLIFFE; GRACE, 2003).

A transgenia certamente pode ser classificada como uma questão sociocientífica por extrapolar fatores científicos e abranger aspectos políticos, econômicos, sociais, éticos, morais, e ainda, por necessariamente ter que passar por uma análise dos contrapontos entre riscos e benefícios. A transgenia pode ainda ser classificada como uma controvérsia da ciência. Ratcliffe e Grace (2003) definem controvérsias da ciência como casos em que as principais questões em debate são as relacionadas com a interação entre questões éticas, políticas e econômicas com a existência de evidência científica.

Alusivo à relação entre educação científica e cidadania, Santos (2007) enfatiza finalidade de propor um quadro teórico no qual a educação científica poderia ser 
direcionada para formação para a cidadania. Para o autor, os contrapontos entre a alfabetização e o letramento científico se constituem por diferenças de concepções acerca do papel da educação científica. As variações de significados incluem o desenvolvimento de habilidades estritamente de conhecimentos científicos - alfabetização científica - e o desenvolvimento de habilidades, conhecimentos e valores relacionados à função social da atividade científica letramento científico. Para Santos, o conhecimento científico não pode ser pensado de forma neutra, sem os contextos sociais envolvidos. Tampouco os contextos sociais podem ser entendidos sem o conhecimento do conteúdo.

Santos (2007) defende que muitas instituições de ensino estão restritas a ensinar conteúdos científicos isentos de estudos epistemológicos e de contexto social. Assim, o ensino por transmissão, pode propiciar a aprendizagem de termos científicos (alfabetização científica), mas dificilmente os alunos conseguem explorar e compreender o significado de tal linguagem.

O autor defende que o estudante letrado seria capaz de compreender impactos da ciência e da tecnologia sobre a sociedade e de agir como consumidor e cidadão, para atuar na decisão de políticas públicas de acordo com valores vinculados a interesses coletivos numa perspectiva de igualdade social, assim:

\footnotetext{
Uma pessoa funcionalmente letrada em ciência e tecnologia saberia, por exemplo, preparar adequadamente diluições de produtos domissanitários; compreender satisfatoriamente as especificações de uma bula de um medicamento; adotar profilaxia para evitar doenças básicas que afetam a saúde pública; exigir que as mercadorias atendam às exigências legais de comercialização, como especificação de sua data de validade, cuidados técnicos de manuseio, indicação dos componentes ativos; operar produtos eletroeletrônicos etc. Além disso, essa pessoa saberia posicionar-se, por exemplo, em uma assembleia comunitária para encaminhar providências junto aos órgãos públicos sobre problemas que afetam a sua comunidade em termos de ciência e tecnologia (SANTOS, 2007, p.480).
}

O letramento científico pode viabilizar a formação de pessoas que considerem não só a questões utilitárias e econômicas da ciência e da tecnologia, mas também aspectos relacionados à saúde, ambiente e questões éticas. Como propõe Santos (2007), o cidadão letrado pode participar de decisões democráticas que definam rumos da ciência e da tecnologia quando são capazes de questionar a ideologia dominante e o desenvolvimento tecnológico.

O letramento científico representa, portanto, uma possibilidade de enfrentamento de perspectivas reducionistas da educação científica. A perspectiva reducionista, segundo Auler e Delizoicov (2001), consiste no ensino restrito aos conceitos, baseada numa visão ingênua por não problematizar mitos referentes à ciência e à tecnologia, uma vez que trata artefatos científicos e tecnológicos por meio de uma dimensão técnica ou internalista e pressupõe um público ignorante no que diz respeito às questões científicas e técnicas. $O$ expert, que é o especialista ou técnico, é o único capaz de solucionar problemas sociais de forma eficiente e ideologicamente neutra. Não há espaço para democracia na tomada de decisão, pois somente o especialista comanda os processos. A ciência e a tecnologia são tratadas como soluções para todos os problemas e necessariamente conduzem ao progresso.

O reducionismo da alfabetização científica e tecnológica exclui a ideia de que situações sociais de países em desenvolvimento não são causadas e nem poderão 
ser resolvidas somente pela ciência e pela tecnologia (AULER; DELIZOICOV, 2001). No caso dos organismos geneticamente modificados, por exemplo, a ciência pode ter contribuído para aumentar a produção de alimentos, porém não há mecanismos científicos e tecnológicos envolvidos no processo de distribuição dos alimentos produzidos. Outro aspecto desconsiderado pela perspectiva reducionista é que o avanço tecnológico não é direcionado por uma lógica interna, pois as decisões que definem as inovações e os caminhos favorecem grupos, o que se caracteriza pela influência de condições econômicas, políticas e sociais, bem como por influências de organizações estatais e privadas. Para o enfrentamento dos mitos e do fatalismo que paralisam o pensamento, o público deveria ter consciência do número de decisões que são tomadas em seu nome (ibid.).

Em consonância, Ratcliffe e Grace (2003) defendem que depender de especialistas é uma tendência preocupante, pois a ascensão da chamada "peritocracia" é uma ameaça à democracia. Para estar pronto diante dos desafios impostos pelos interesses políticos e econômicos da peritocracia, os alunos precisam começar a reconhecer a natureza do conhecimento científico, as razões pelas quais os especialistas discordam, os problemas que ocorrem quando tais embates acontecem e a maneira com que conhecimentos científicos são retratados na mídia.

Segundo Priest (2013), para que o público possa decidir se confia ou não nos resultados da ciência, é preciso que possam se fundamentar na compreensão e avaliação das instituições e práticas sociais que produziram os resultados. Embora normalmente se assume que a conduta de uma pesquisa foi direcionada por cientistas éticos que buscam o conhecimento de forma desinteressada, podem ocorrer exceções, e, ainda que em vias honestas, o pensamento de um cientista pode ser distorcido por próprios pontos de vista e diversos outros motivos, como erros de equipamentos ou procedimentos. $O$ entendimento da ciência como um consenso social entre especialistas após avaliações e testes neutros e sem maiores interesses não é uma compreensão que sempre retrata a realidade do desenvolvimento científico.

A educação científica, portanto, precisa tornar a natureza da ciência em um objeto de ensino no cotidiano da sala de aula, visto que um cidadão letrado deve estar preparado para avaliar aspectos epistemológicos das informações divulgadas na mídia com vista a extrair avaliações e conclusões ponderadas.

No entanto, os estudos acerca da natureza da ciência são constantemente excluídos dos currículos escolares, assim, carece de ênfase e pouco se sabe a respeito da eficácia do ensino e da aprendizagem de tal conteúdo (RATCLIFFE; GRACE, 2003). Muitas vezes a epistemologia da ciência é reduzida ao tratamento do método científico em sala de aula, o que leva ao entendimento de que existe um modelo único e fechado da visão do desenvolvimento científico. O caminho tão determinado, fechado e óbvio que o método científico aparenta no que se refere à ciência não explora as características científicas de forma realista por não questionar interpretações que pode ter o cientista, ou interpretações próprias do momento vigente que está imerso em um estilo de pensamento científico (FLECK, 1986). O método científico, para muitos, se mostra infalível e possuidor da suposta neutralidade da ciência (PRAIA; GIL-PEREZ; VILCHES, 2007).

Seria necessário então o estabelecimento de debates e problematizações no currículo escolar que propiciam questionamentos como: Quão esclarecidos estão 
os efeitos prejudiciais dos transgênicos sobre o ambiente atualmente? Qual é a natureza da evidência científica apresentada? Como foi estabelecida? Afinal, o conhecimento científico resulta de criação e interpretação social e não de uma revelação ou uma descoberta da realidade (SOUSA et al., 2011). A ciência e seus produtos não fornecem explicações definitivas do mundo, mas representam uma das múltiplas formas de entendê-lo.

Uma posição enganadora que toma uma suposta lógica interna da ciência como eixo direcionador exclusivo de instâncias de decisão pública não pode se colocar acima das necessidades sociedade, sem que esta tenha exercido sua participação. Pensando formas de articulação da sociedade com âmbitos de decisão pública, modos ou níveis de participação pública serão caracterizadas adiante.

\section{PARTICIPAÇÃO PÚBLICA E TRANSGENIA}

A relação da elaboração de políticas públicas de tecnologia e ciência com o público pode estar se estabelecer por meio de diferentes perspectivas. Uma delas é a que pressupõem um público receptor como um sujeito passivo e manipulável, ou seja, um repositório vazio que recebe conteúdos absolutos e acabados. Como contraponto, uma outra perspectiva considera que o receptor pode ser entendido como o indivíduo que necessita estar incluso no processo de elaboração de políticas públicas de ciência e tecnologia. Nesta perspectiva, o conhecimento da sociedade é entendido como fruto de experiência acumulada, que podem compor políticas públicas democráticas que almejam legitimidade ao reconhecer a expertise leiga (Sousa et al., 2011).

A Comissão Europeia emprega atualmente diálogos abertos como parte da nova parceria estabelecida entre a ciência e a sociedade, o que se opõe às antigas formas de mera comunicação unilateral. Conferências realizadas com grupos de cidadãos proporcionam o conhecimento acerca das perspectivas importantes da sociedade que contribuem com questões técnicas (IRWIN, 2008). Nelas são discutidas as decisões referentes à ciência e tecnologia que terão impactos sobre a vida dos cidadãos. A Responsible Research and Innovation (RRI), por exemplo, é um programa europeu que busca fomentar pesquisas e inovações responsáveis por meio do estreitamento da relação entre a ciência e os valores, as necessidades e as expectativas da sociedade (ver mais em European Commission, 2015). No Reino Unido, há alguns processos e métodos para a realização de debates públicos que precedem processos decisórios: 0 governo pode trazer um documento de consulta acerca de uma questão política, ou anunciar uma proposta referente a uma mudança na legislação por meio de um Green Paper ou White Paper para obter respostas do público em geral ou de um público específico. A opinião pública pode ser consultada através de enquetes, entrevistas ou grupos focais (UNITED KINGDOM, 2003). É um objetivo europeu reforçar a relação entre cientistas, pesquisadores, educadores de ciências e os meios de comunicação para garantir uma comunicação pública mais eficaz, de maneira que questões científicas e tecnológicas, bem como as consequências envolvidas sejam compreensíveis pelos cidadãos. Nas diretrizes, está incluso que os educadores de ciência têm a responsabilidade de incorporar princípios sociais, econômicas e éticos no ensino, 
No que concerne à relação entre o governo e a sociedade no que diz respeito à prática democrática e à participação pública, a taxonomia de Irwin (2008) propõe uma interpretação configurada em níveis de primeira, segunda e terceira ordem de engajamento na ciência e representa um modelo importante para embasar a discussão de como os processos democráticos podem apresentar diferentes graus de fornecimento de oportunidades de participação pública.

o que o autor denomina como engajamento de primeira ordem é a comunicação unidirecional, por meio da qual o público aprende mais acerca de perspectivas científicas, mas os cientistas não aprendem mais a respeito de perspectivas públicas. No modelo de primeira ordem, autoridades utilizam uma linguagem baseada na certeza fornecida pela ciência, que é apresentada como absolutamente central para toda a questão. Os consumidores devem ser "protegidos" e não consultados. Trata-se de um modelo "de cima para baixo" de comunicação (IRWIN, 2008).

O engajamento de segunda ordem de Irwin é a perspectiva de diálogo, que é configurada com base no pressuposto de que especialistas e não-especialistas tem conhecimentos valiosos para oferecerem uns aos outros. $O$ objetivo é o alcance de um diálogo de duas vias que permita a troca de perspectivas e conhecimento entre a ciência e o público. Já o engajamento de terceira ordem é aquele em que o desenvolvimento científico é direcionado ao atendimento de necessidades sociais. Trata-se de incluir os valores públicos nas relações que definem a incorporação de inovações, prioridades institucionais e concepções amplas referentes ao bemestar social e justiça (IRWIN, 2008).

No Reino Unido em 2003, um debate público referente aos OGM (organismos geneticamente modificados) $)^{1}$ foi realizado com a finalidade de oportunizar um espaço para que a população britânica declarasse o que sentia a respeito da nova tecnologia e o cultivo comercial GM (geneticamente modificado). O evento denominado GM Nation deveria ser classificado no engajamento de segunda ordem da taxonomia de Irwin (a perspectiva do diálogo entre especialistas e nãoespecialistas), porém os resultados do debate impedem tal classificação. $O$ objetivo geral do evento era fornecer informações significativas para o governo acerca das opiniões do público para informar a tomada de decisão (IRWIN, 2008). No desfecho do debate, foram obtidas conclusões de que as pessoas apresentam inquietações referente aos organismos geneticamente modificados; e entendeuse que quanto mais as pessoas se envolvem com questões GM, há maior atitude de rejeição e maiores são as preocupações; há pouco apoio para a comercialização e há desconfiança generalizada da população acerca do governo e de empresas multinacionais (UNITED KINGDOM, 2003).

Para Irwin (2008), a forte rejeição aos OGM no GM Nation pode ser o resultado da dominação do debate por ativistas, o que implicou em uma participação muito restrita e em um debate com pouca profundidade e abrangência. Para o autor, a esperança de que tal exercício do engajamento levaria ao consenso social, ou à maior aceitação aos OGM, foi certamente decepcionada.

${ }^{1}$ Transgênicos e organismos geneticamente modificados (OGMs) muitas vezes são utilizados como sinônimos, tanto na Págiñ̂巾 os transgênicos são, de fato OGMs, mas nem todos os OGMs são transgênicos uma vez que, o gene que o transgênico recebe é, necessariamente, proveniente de um organismo de outra espécie (SOUZA; FARIAS, 2011). 
Para alcançar avanços na relação entre o governo e a sociedade, é preciso ter em vista que a comunicação não se realiza por meio de conceitos acabados ou consensos teóricos, mas tem natureza polifônica, uma vez que se constrói por meio da interação de muitas vozes (SOUSA et al., 2011), o que retoma a importância da perspectiva do diálogo proposta por Irwin na segunda ordem de engajamento na ciência. Com vistas a explorar brevemente perspectivas acerca dos transgênicos no Brasil e no mundo, a próxima seção introduz algumas considerações, não com o intuito de polarizar a discussão, mas de apontar uma caracterização geral da transgenia e o caráter plural de modos de conceber essa prática científica e tecnológica.

\section{TRANSGÊNICOS NO BRASIL E NO MUNDO}

Na última década, a pesquisa biológica mediada pela engenharia genética permitiu a determinação de sequências completas do DNA de algumas espécies, a clonagem de organismos e a produção de organismos geneticamente modificados. Tais técnicas são acompanhadas por promessas de empresas multinacionais, como a Monsanto, referentes a um aumento da capacidade científica de aplicar conhecimentos biológicos a problemas globais. Quando se pensa nas aplicações tecnológicas dos conhecimentos de DNA, por exemplo, notabiliza-se um aumento das possibilidades para a agricultura, legislações criminais e pesquisas médicas. Porém, as implicações éticas e sociais - inerentes ao processo de incorporação de biotecnologia - causam preocupações em diferentes nações (GUIVANT, 2006; HOBAN, 2004).

A ampliação de técnicas e de aparatos biotecnológicos propiciam novas formas de aumentar a produção alimentícia, como é o caso dos alimentos geneticamente modificados. A promessa de maior produtividade agrícola - que seria garantida pelas características de interesse artificialmente introduzidas nos cultivos - trouxe expectativa de redução dos preços a esperança de que se estabelecesse um processo de igualdade de acesso aos alimentos, o que em última análise, solucionaria ou minimizaria o problema da fome.

O processo de clonagem gênica é um exemplo de procedimento utilizado para a produção de cópias de um determinado gene ou para a produção de proteínas específicas (como a insulina destinada a pacientes diabéticos). Outra aplicação da clonagem gênica é a produção de cópias de um gene de interesse que será responsável por determinar um fator desejável em um organismo. Os seres vivos que recebem genes de interesse de outras espécies são os organismos transgênicos. Os primeiros alimentos que sofreram modificações por meio da transgenia foram o tomate, a soja, a batata e o milho, que se tornaram mais resistentes a agrotóxicos e a algumas pragas (LAJOLO; NUTTI, 2003).

A história dos transgênicos é relativamente recente e foi iniciada quando empresas que comercializavam pesticidas e herbicidas iniciaram a produção de sementes transgênicas. A empresa norte-americana Monsanto comprou a maior parte da nova tecnologia transgênica, e, para estabelecer aceitação entre fazendeiros e consumidores, lançou diversas companhas publicitárias. Em 1999, $55 \%$ da soja e $35 \%$ do milho produzido nos Estados Unidos eram transgênicos e a produção transgênica também estava se desenvolvendo na China. Nas campanhas, a Monsanto defendia que transgênicos ajudariam a resolver o problema mundial 
da fome e reduziria problemas de poluição química causada por agrotóxicos (GIDDENS, 2012).

Atualmente, $80 \%$ da área mundial de cultivos GM (geneticamente modificados) se distribui entre Estados Unidos, Argentina e Brasil (REECE et al., 2015). O Brasil é o segundo país com maior área de lavouras GM com 40,3 milhões de hectares (abaixo apenas dos Estados Unidos) e representa a maior taxa de crescimento de área GM plantada por ano no mundo (JAMES, 2013).

Procedimentos laboratoriais que se referem à utilização de genes específicos para aplicações diversas são desenvolvidos por cientistas que reproduzem múltiplas cópias idênticas de DNA (clonagem do DNA), um processo frequentemente realizado por meio da inserção de genes em plasmídeos (moléculas circulares de DNA) da bactéria Escherichia coli. O plasmídeo bacteriano que recebe um DNA "estranho" passa a ser denominado DNA recombinante, visto que passa a conter DNA de duas fontes diferentes, normalmente de espécies diferentes. Por meio de repetidas divisões celulares, tem origem uma população de células bacterianas geneticamente idênticas, visto que todas as descendentes das bactérias recebem um plasmídeo recombinante. O "corte" de sequências gênicas é realizado de maneira muito específica devido ao emprego das enzimas de restrição - moléculas proteicas capazes de reconhecer sequências curtas de DNA e que cortam as fitas do DNA em pontos precisos. As novas associações de partes de DNA diferentes são realizadas pela enzima DNA-ligase, que forma ligações entre os esqueletos das fitas de DNA (REECE et al., 2015).

Para produção de plantas transgênicas, a bactéria comumente utilizada é a espécie Agrobacterium tumafaciens (REECE et al., 2015). Sequências de DNA de interesse são introduzidas no plasmídeo da bactéria para reprodução dos genes e posterior introdução em plantas hospedeiras. A bactéria $A$. tumafaciens é capaz de infectar células de plantas e transferir parte do seu material genético para um tecido vegetal (LAJOLO; NUTTI, 2003), uma característica facilitadora do processo de introdução do gene, o que explica a ampla utilização dessa espécie de bactéria na transgenia de plantas.

Já o milho, o algodão e a batata contém genes da bactéria Bacillus thuringiensis que codificam uma proteína tóxica aos insetos-praga. A proteína, embora letal para insetos, é inofensiva a vertebrados que possuem estômago ácido, uma vez que a proteína só mantém a configuração ativa em meios alcalinos. Plantas resistentes a doenças virais também são produzidas atualmente (REECE et al., 2015). No Brasil, A Embrapa (Empresa Brasileira de Pesquisa Agropecuária) desenvolve o mamão resistente ao vírus que provoca a "mancha anelar", o feijão resistente ao vírus do mosaico dourado e a batata resistente ao vírus que provoca o "enrolamento da folha" (LAJOLO; NUTTI, 2003).

Os defensores da biotecnologia vegetal argumentam que uma vez que agricultores deverão produzir $40 \%$ mais grãos por hectare para garantir a alimentação humana em 2030 (REECE et al., 2015); para eles, a superação da fome mundial pode ser viabilizada pelos benefícios da produção transgênica, como o aumento da durabilidade e a proteção contra "agressores externos" (LAJOLO; NUTTI, 2003). Dois possíveis benefícios decorrentes do cultivo de plantas transgênicas resistentes a herbicidas e ao ataque de pragas ou doenças são a redução do uso de inseticidas químicos e a redução da mecanização para retirada de plantas daninhas, o que reduziria a erosão do solo. 
Acerca de riscos do emprego da transgenia em animais, Reece et al. (2015) consideram que as proteínas produzidas em animais de fazenda transgênicos para uso humano diferem daquelas produzidas naturalmente no organismo humano. Sendo assim, a produção deve ser testada cuidadosamente para que não resultem em reações alérgicas ou outros efeitos indesejados nos consumidores.

A transgenia é também utilizada para produção e introdução de genes que aumentam o desenvolvimento muscular de bovinos e caprinos. Os genes são introduzidos em outra raça bovina ou para ovelhas e carneiros. Constantemente são observados problemas como baixa fertilidade ou maior suscetibilidade para doenças entre tais animais transgênicos, o que implica na necessidade de maiores pesquisas antes da ampliação de tal técnica (REECE et al., 2015).

Parte da cautela em relação ao cultivo de transgênicos se deve a receios da sociedade referentes a aspectos ambientais, como: (a) a possibilidade de passagem de genes para plantas selvagens vizinhas das plantações transgênicas (transferência de pólen), (b) a possibilidade de aumento de resistência das plantas daninhas e (c) a possibilidade de aumento de resistência de insetos-praga; receios também se devem a aspectos referentes à saúde humana devido a: (1) à possibilidade de reações alérgicas aos alimentos GM, (2) à possibilidade de transferência de genes para células humanas ou para micro-organismos intestinais e (3) à possibilidade de genes marcadores presentes nos transgênicos gerarem resistência a antibióticos em bactérias intestinais (REECE et al. 2015; GIDDENS, 2012).

$\mathrm{Na}$ Europa, uma fase de rejeição aos transgênicos ganhou força principalmente após a pesquisa de Arpad Pusztai referente ao consumo de transgênicos por ratos de laboratórios causar danos no sistema imunológico e redução no crescimento dos órgãos (EWEN; PUSZTAI, 1999). Embora o autor tenha sido criticado por outros cientistas, o debate referente aos transgênicos, principalmente na Europa, reduziu significativamente a aceitação que a Monsanto esperava ter. O diretor da Monsanto admitiu na televisão os erros da empresa no que diz respeito à excessiva confiança e entusiasmo com a nova tecnologia. $\mathrm{Na}$ época, o plano de utilizar o gene "terminator", que seria capaz de tornar as sementes estéreis após uma geração (o que obrigaria os produtores a comprar sementes todo ano) foi proibido (GIDDENS, 2012).

Como colocam Hedgecoe e Martin (2007), os esforços governamentais direcionados à promoção biotecnológica, incorporados ao cenário do desenvolvimento econômico, apesar de normalmente proporcionarem condições de prosperidade econômica, oferecem o contraponto de reais preocupações bioéticas. Análises e críticas se focam na maneira de produção da tecnologia, bem como pressupostos que sustentam a utilização e o impacto sobre a sociedade, uma vez que a biotecnologia modifica relações sociais de produção de conhecimento, por meio do patenteamento de genes e do aumento das relações da ciência com a indústria, o que restringe o acesso público à informação.

Grande parte da insatisfação em relação à incorporação de biotecnologias à produção se deve ao distanciamento entre o cientista e o público. Dificilmente as mídias publicam informações acerca dos passos para o desenvolvimento de uma biotecnologia, acerca dos motivos que estimularam a produção ou um debate acerca dos potenciais riscos e benefícios para os consumidores. Debater riscos publicamente é um passo muito importante para a garantia de que os cidadãos 
possam formar a própria opinião para participar de processos de decisão pública. O conhecimento dos riscos envolvidos na manipulação genética não gera fatalismo, mas induz o estabelecimento de novas relações de si mesmo com o futuro e um novo conjunto de obrigações e responsabilidades biológicas (NOVAS; ROSE, 2000).

Lajolo e Nutti (2003) defendem que a segurança nos alimentos transgênicos é a mesma dos outros alimentos, visto que há muitas etapas de avaliação e testes. Os autores argumentam que com base nos resultados obtidos nos procedimentos de avaliação não é necessário empregar aos transgênicos o princípio de precaução. Aplicar o princípio de precaução à segurança de alimentos implicaria em exigir a ausência completa de efeitos adversos. O princípio da precaução consiste em seguir práticas existentes enquanto novos processos não estão esclarecidos no que diz respeito aos riscos possíveis, ou seja, quando ainda há dúvidas suficientes acerca dos riscos, processos novos não devem entrar em uso (GIDDENS, 2012). Porém, Lajolo e Nutti (2003) defendem que a ingestão de DNA recombinante presente nos alimentos transgênicos não apresenta riscos devido ao número reduzido em relação ao restante de DNA ingerido a partir de outros alimentos e devido à degradação que normalmente ocorre pela acidez e ação de enzimas na digestão.

No que se refere aos efeitos não-intencionais de produtos GM, os autores afirmam que a investigação é realizada a partir de técnicas que detectam diferenças causadas pela modificação genética de forma global, "em vários níveis do metabolismo, desde mudanças do DNA, no perfil dos RNAm, de proteínas e de metabólitos produzidos (LAJOLO; NUTTI, 2003, p. 73)".

Embora parte dos cientistas e algumas instituições, como a Embrapa, declarem com veemência que os transgênicos são seguros, populações de diferentes nações ainda estão receosas quanto aos riscos. Sendo assim, é necessário que instâncias governamentais, científicas e privadas se reúnam em favor de um debate aberto para informar a população de forma devidamente equilibrada e plural acerca das implicações sociais, ambientais, econômicas e políticas da ampla utilização da biotecnologia transgênica. É de fundamental importância, que além da responsabilização referente à divulgação de informação, tais instâncias também se comprometam com a inclusão da participação pública na tomada de decisão de regulamentações e políticas públicas relacionadas aos transgênicos.

No início da inserção da transgenia na agricultura do Brasil, as decisões foram tomadas de maneira centralizada, sem considerações acerca da opinião pública. Segundo Ferreira (2015), o cultivo de soja transgênica foi legalizado em 2003, porém já era realizado ilegalmente em solo brasileiro. Para ilustrar o processo unilateral de decisão da época, é possível citar as condições da Comissão Técnica Nacional de Biossegurança (CTNBio) que reunia 27 membros para tomar decisões acerca do desenvolvimento de atividades que envolviam transgênicos. Apenas seis deles eram indicados pela sociedade, quando o total de 14 votos seria suficiente para aprovação das atividades envolvendo transgenia (FERREIRA, 2015). Tal proporção indica a reduzida representatividade da opinião da sociedade, que não estava presente em um número suficiente para aprovar qualquer decisão. $A$ regulamentação inicial da introdução da transgenia no Brasil foi delineada por um modelo decisório cientificista, de modo a restringir o direito da participação pública e plural nos processos de tomada de decisão. 
Em 2015, um projeto de lei brasileiro começou a ser discutido para que o símbolo "T" dentro de um triângulo amarelo com bordas pretas (que indica a presença de ingredientes transgênicos) não estivesse mais presente nos rótulos de embalagens. Na nova proposta, apenas a informação de que há ingredientes GM com porcentagem superior a $1 \%$ em determinado alimento deveria estar presente por extenso, mas sem o símbolo. A proposta limita a rotulagem, uma vez que atualmente o símbolo que indica a presença de transgênico não se refere a uma porcentagem, mas à presença em qualquer proporção de ingrediente GM (PIACENTINI, 2015).

Embora em abril de 2015 a Câmara dos Deputados tenha aprovado o projeto de dispensa do símbolo (ver Câmara dos Deputados, 2015), em outubro de 2015, no site do Senado Brasileiro, a Comissão de Ciência, Tecnologia, Inovação, Comunicação e Informática (CCT) declarou que rejeitou o projeto que retira a obrigatoriedade de estampar o símbolo. O Instituto Brasileiro de Defesa do Consumidor (IDEC) e a Agência Fiocruz argumentam em defesa da manutenção da legislação antiga da rotulagem, ver mais em IDEC (2015) e Fiocruz (2015). O público foi consultado por meio de uma enquete online, onde consta o texto da nova proposta na íntegra para consulta e posterior escolha de posicionamento "a favor" ou "contra". Em um resultado parcial até o início de 2018, foram obtidos 876 votos a favor e 15.184 votos contra o projeto - ver Senado Federal (2015). O projeto ainda se encontra em tramitação no Senado e prossegue, ainda que a maioria da população participante da enquete se declare "contra".

Assim, no Brasil e em diferentes partes do mundo, a introdução da transgenia é entendida por visões contrastantes. No Brasil, alguns casos de oposição extrema são identificados: por exemplo, a invasão de integrantes do MST (Movimento dos Trabalhadores Rurais Sem Terra) no cultivo de eucalipto transgênico em 2015. Houve destruição de estufas e mudas, justificada pelos invasores com a alegação de que o plantio causaria danos ambientais.

Embora enfrente hostilidade, a biotecnologia transgênica avança no Brasil e em outras partes do mundo. Em 2016, na cidade de Piracicaba no Estado de São Paulo, por exemplo, foram liberados mosquitos Aedes aegypti transgênicos com a capacidade de produzir proles inférteis. O projeto é uma resposta à ineficácia de outras medidas profiláticas dirigidas ao mosquito transmissor de dengue, febre chikungunya e zica.

Tendo em vista a apresentação de um quadro referente às diferentes condições de aceitação da transgenia, será apresentada a seguir uma breve comparação entre algumas pesquisas de opinião pública realizadas em alguns países.

\section{OPINIÃO PÚBLICA A RESPEITO DA TRANSGENIA}

Segundo Sousa et al. (2011), instâncias governamentais brasileiras não se responsabilizam por informar a sociedade no que diz respeito à tecnologia dos transgênicos ou no que concerne à regulamentação nacional e mundial atualmente instituída. Os autores defendem que, tendo em vista a lacuna deixada pelo governo nacional, organizações (como Monsanto e Greenpeace) posicionadas em defesa de interesses próprios, levam ao público argumentos fragmentados com alegações acerca dos riscos e benefícios do cultivo e consumo de transgênicos. 
Tais emissoras fazem uso da comunicação como um artifício para advogar em causa própria.

Enquanto Greenpeace recorre a estereótipos de fácil identificação e caricaturas para propagar informações superficiais e incompletas, Monsanto recria livremente a história de uma comunidade local para oferecê-la como caso supostamente emblemático das populações que teriam sido salvas da fome e da pobreza pelo "milagre" da transgenia (SOUSA et al., 2011, p.37).

Em consonância, os participantes da pesquisa realizada por Furnival e Pinheiro (2008) afirmam que a mídia brasileira não fornece explicações claras e declaram que tem incertezas, dúvidas e desconhecimento de informações acerca da incorporação de transgênicos nos alimentos. É pela mídia que, a maioria declarou receber informações referentes aos transgênicos, mas declaram não compreender as divulgações, ainda que acompanhem as notícias. Muitos participantes defendem a rotulagem dos produtos que contém transgênicos, porém admitem não ser uma medida suficiente para auxiliar na tomada de decisão acerca do consumo dos produtos.

Guivant (2006) fez um levantamento de pesquisas da percepção pública de ciência e transgênicos e concluiu que pesquisas de opinião pública são escassas no Brasil. A autora afirma que tal condição é um reflexo da desconsideração da participação pública nos debates de transgênicos.

Hoban (2004) ao discutir pesquisas realizadas em alguns países, se depara com grandes diferenças nos estudos de opinião pública em cada nação, o que é observado também no Brasil. $O$ autor propõe que as respostas obtidas nas pesquisas são muito sensíveis às condições que a constituem, como a redação das perguntas, os métodos empregados para a seleção dos entrevistados, o tipo de informação fornecida aos entrevistados e o tamanho da amostra. Para Hoban, tais fatores podem influenciar os resultados substancialmente.

De forma geral, a partir das pesquisas, pode-se afirmar que chineses e indianos são, em grande parte, favoráveis às culturas geneticamente modificadas, e, entre os consumidores dos Estados Unidos e Canadá também há apoio aos transgênicos. Entretanto, na Europa e na Austrália há uma significativa rejeição aos alimentos geneticamente modificados (HOBAN, 2004) assim como na África que por várias vezes rejeitou doações de milho e soja geneticamente modificadas por receio de redução da diversidade agrícola do país (GIDDENS, 2012).

O Eurobarômetro, instrumento da União Europeia para avaliar opinião pública, na pesquisa de 2002 obteve um total de 70,9\% dos europeus que rejeitavam alimentos geneticamente modificados (GUIVANT, 2006). Houve uma época em que os transgênicos eram matéria de primeira página dos jornais quase todos os dias na Europa. Debates na televisão e no rádio foram organizados para discutir a questão. No Reino Unido, sete das oito redes principais de supermercados alteraram a política de alimentos transgênicos. Cinco das principais redes baniram totalmente ingredientes transgênicos dos produtos de suas marcas (um processo ainda em andamento) e todas insistiram na rotulagem adequada (GIDDENS, 2012).

Hoban (2004), considera que somente à medida que benefícios para a dieta e para a saúde se tornam aparentes, a aceitação do consumidor aumenta. Acerca dos estudos internacionais supracitados, o autor pontua que o conhecimento 
técnico não é um pré-requisito de aceitação do consumidor (visto que na Ásia, por exemplo, onda há grande aceitação, o nível de conhecimento técnico referente a biotecnologia é baixo). O autor defende que a comunicação clara dos riscos e benefícios reais (não hipotéticos) relacionados com os alimentos são uma parte essencial do processo de aceitação.

Guivant (2006) considera, assim como Hoban (2004) que mais conhecimento não necessariamente implica em aceitação de uma inovação tecnológica controversa. Normalmente, segundo a autora, pessoas mais informadas tendem a evitar posições restritamente favoráveis ou contrárias.

A pesquisa de opinião pública precisaria ser prioridade de órgãos públicos desde o início de um direcionamento para tomada de decisão. Os debates não realizados, as informações não disponibilizadas e a participação pública não concretizada são embates constantemente atribuídos às instâncias governamentais, empresariais ou científicas. Mas diante desse cenário de desinformação, qual seria o papel da educação científica tendo em vista o preparo para a tomada de decisão esclarecida acerca dos transgênicos? Nesse contexto tem importância a reflexão: no Brasil, como o público estaria preparado para dialogar em instâncias públicas para contribuir com conhecimentos obtidos por meio da experiência cotidiana e para compreender as informações que serão fornecidas pelos especialistas para promoção do engajamento? O preparo para o diálogo com especialistas em esferas públicas seria uma função da educação formal? Admitindo que seja função da educação formal a formação de estudantes que são capazes de tomar decisões esclarecidas acerca de questões sociocientíficas, como transgenia, é proposta a seguir uma estratégia didática.

\section{ESTRATÉGIA DIDÁTICA PARA O CONTEÚDO DE TRANSGENIA}

Praia, Gil-perez e Vilches (2007) propõem que um modelo adequado para anteder à demanda da educação científica e da formação para ação cidadã é o ensino por investigação, ou seja, inserir o aluno na prática científica. Assim, podese propor atividades abertas e criativas orientadas pelo professor por meio de situações problemáticas. O objetivo das atividades é que os alunos possam enfrentar problemas relevantes e reconstruir conhecimentos científicos tendo em vista aspectos sociais, morais e atitudinais da educação científica. Para os autores, as atividades devem ser em espaços que proporcionem o uso repetido dos novos conhecimentos numa variedade de situações, que contribuam para um aprofundamento e enfatizem principalmente as relações CTSA (Ciência, Tecnologia, Sociedade e Ambiente). Nelas, é importante destacar as repercussões de conhecimentos científicos e tecnológicos de forma a abordar as contribuições da ciência para o desenvolvimento da humanidade, bem como os graves problemas que ameaçam o futuro.

Tais atividades, diferentes do ensino por transmissão de conteúdo, têm maiores potencialidades para o ensino da natureza da ciência. Uma das importantes funções dos estudos da natureza da ciência é a possibilidade de propiciar aos alunos a capacidade de análise de informações científicas veiculadas na mídia. Na educação formal, as discussões seriam enriquecidas se notícias de questões sociocientíficas levadas para a sala de aula fossem analisadas quanto à 
relevância das evidências apresentadas, a forma como foram obtidas e os interesses envolvidos, por exemplo (SANTOS, 2007).

Mas como a educação formal poderia preparar os estudantes para compreender um quadro problemático de uma controvérsia científica a partir das informações disponibilizadas pela mídia? Tendo em vista que em tempos de internet, embora a informação esteja disponível, haverá diversos posicionamentos postados em forma de artigos, notícias, comentários ou vídeos, e o desafio será que o leitor terá que analisar e formar a própria opinião diante das exposições consultadas. Um desafio ainda maior está em como a educação formal poderia preparar as pessoas para o exercício da cidadania em debates abertos de audiências públicas, nos quais diferentes pontos de vistas seriam sequencialmente apresentados, sendo alguns deles constituídos por falácias que teriam que ser detectadas e questionadas.

Defendemos que a educação científica comprometida com a formação para a cidadania por meio do letramento científico poderia propiciar ambientes de debates acerca de situações reais ou hipotéticas de forma que os alunos possam ouvir e mobilizar argumentos sendo orientados pelo professor (ou professores). Assim, tendo em vista as questões formativas da educação científica discutidas, propõe-se uma possibilidade de estratégia didática que seja exequível em aulas da Educação Básica, a partir de uma atividade cujo embasamento sejam as "atividades de diálogo" e o "role-playing" (estratégias de ensino de atitudes) e que busque contemplar uma formação mais sistêmica e um posicionamento crítico e fundamentado dos alunos.

Segundo Sarabia (2000), "atividades de diálogos" são importantes para o ensino de atitudes científicas. Normalmente as atividades são caracterizadas por personagens reais que ocupam seu próprio papel e tratam de assuntos de interesse acadêmico ou humano. $O$ ensino é potencializado porque os alunos tendem a lembrar dos próprios argumentos, devido ao caráter ativo do exercício do debate. Já as atividades denominadas por Sarabia (2000) como "role-playing" consistem em dramatização ou representação mental da adoção do papel de outra pessoa. O objetivo é produzir mudanças na percepção e na avaliação de uma outra pessoa. Na educação formal uma possibilidade para o preparo do exercício da cidadania seria propor atividades mistas de "diálogo" e "role-playing" em debates.

Acerca dos transgênicos, uma possível atividade seria um debate entre participantes que seriam divididos em três grandes grupos: (a) uma empresa fictícia que comercializa sementes transgênicas e agrotóxicos, (b) uma ONG fictícia que se opõe à produção de transgênicos e (c) a sociedade que se comporta como uma espécie de júri, o grupo com maior número de alunos. Em sessões categorizadas por temas, o júri dirige perguntas a ambos os grupos (empresa e ONG), e quando houver discordâncias, empresa e ONG podem debater entre si. A atividade poderia ser realizada por sessões em dias diferentes para permitir aos alunos um tempo para investigação de novas informações.

$\mathrm{Na}$ atividade, o grupo da empresa de transgênicos e o grupo da ONG podem ser classificados como uma atividade role-playing, enquanto o grupo que representa a sociedade é classificado numa atividade de diálogo. Em cada sessão, os alunos poderiam ocupar papeis diferentes para que seja possível o desenvolvimento de habilidades dos dois tipos de atividades (diálogo e roleplaying). 
O modelo da atividade, em parte, é justificado porque em festivais de ciência do Reino Unido, o público se queixa da ausência de debates entre os oradores. Alguns argumentam que $o$ debate entre especialistas que defendem seus respectivos pontos de vista é a melhor forma de apresentar a ciência ao público (JENSEN; BUCKLEY, 2014).

Defendemos que os alunos precisam analisar informações disponibilizadas na mídia, nos livros didáticos e em artigos científicos ao longo de algum tempo, antes da formação dos grupos da empresa, da ONG e do júri. Antes dos debates, pautas poderiam ser elaboradas pela turma referentes aos pontos a serem questionados para a empresa e para a ONG, mas uma questão geral a ser respondida por cada aluno participante ao final é: Quais os riscos e benefícios envolvidos no emprego da biotecnologia de transgênicos?

$\mathrm{Na}$ realização da atividade, quando o professor perceber falácias ou informações fragmentadas, deve haver problematização. Não se faz necessária a proibição de argumentos falaciosos, uma vez que podem suscitar problematizações acerca da natureza da divulgação de informações acompanhadas por interesses de grupos específicos. Porém, falácias deveriam ser sempre identificadas e discutidas para que o exercício de identificação de informações fragmentadas ou parciais seja constante, de modo a permitir a aprendizagem sobre tal exercício.

É necessário o cuidado para que o debate não se torne tendencioso. A identificação de um problema não pode ser polarizada no sentido de um ponto de vista, assim a apresentação de evidências deve se referir a dois ou mais pontos de vista diferentes - o que poderia ser garantido com a sequência de respostas da "empresa" e da "ONG" até que a "sociedade" (o grupo que representa a sociedade) estivesse satisfeita com as informações mobilizadas.

Segundo Ratcliffe e Grace (2003), não é realista supor que seja possível a avaliação da mudança de comportamento ou de rotina dos alunos, porém é possível avaliar o desenvolvimento de opinião e atitude (precursores de ação). A tomada de decisão implica a finalização e ação (comportamento) enquanto a formação de opinião, não implica. Assim, a finalidade da atividade é o desenvolvimento de "opinião esclarecida", um objetivo que deve ser alcançado em se tratando do ensino referente aos transgênicos.

Espera-se que os alunos possam desenvolver habilidades de identificação de interesses incrustados em discursos midiáticos e de interesses presentes nos discursos governamentais ou científicos. Espera-se ainda que os alunos possam ponderar as próprias opiniões considerando aspectos éticos e ambientais para declarar as próprias ideias. Assim, para além de responder se "é contra ou a favor?", é solicitado que os estudantes respondam quais são os riscos e benefícios do emprego de transgênicos. Estar contrário ou favorável à transgenia são posições que não precisam necessariamente ser visadas como objetivo de aprendizagem. Em diferentes situações, os estudantes devem ser capazes de ponderar riscos e benefícios para que se posicionem em uma votação, por exemplo. Dada a multiplicidade de circunstâncias nas quais a transgenia pode estar inserida, "ser contra ou a favor" de modo absoluto não representa necessariamente uma opinião esclarecida sobre o tema. Ser capaz de apontar adequadamente riscos e benefícios (referentes à saúde, ética, ambiente, etc.) envolvidos em questões sociocientíficas e ser capaz de participar de uma instância 
democrática de deliberação (ou de participar de outros âmbitos de transformação da realidade) são habilidades que devem ser objetivos de predileção da escolarização.

\section{CONSIDERAÇÕES FINAIS}

A área da biotecnologia que se ocupa com estudos e pesquisas de transgênicos é mundialmente empregada para diferentes fins. Decisões referentes à regulamentação da pesquisa, à utilização de organismos transgênicos e ao cultivo de plantas transgênicas foram tomadas por instâncias políticas em diferentes países, com algumas exceções, sem participação pública, principalmente devido à forma centralizada do processo decisório e à desinformação da sociedade acerca dos riscos e benefícios oferecidos ao ambiente, à saúde humana e à economia. $\mathrm{O}$ constante aumento da utilização de organismos transgênicos, principalmente na agricultura, é uma situação que preocupa sociedades de várias nações, devido às incertezas referentes aos possíveis riscos fornecidos aos ecossistemas e à saúde de todos os seres vivos - temática raramente debatida em espaços públicos.

Embora seja necessário admitir que no Brasil ainda não se estabeleceram muitas oportunidades para o debate aberto entre especialistas e não-especialistas, ou para consulta e participação pública, é consenso inclusive nos Parâmetros Curriculares Nacionais (BRASIL, 1997) que a educação formal tem como objetivo a formação para a cidadania e a preparação dos estudantes para situações em que se possa pedir por participação em processos decisórios no âmbito das políticas públicas. Nessa perspectiva, o papel da educação científica para o exercício da cidadania poderia estar centrado não só no ensino de conteúdos conceituais, mas no desenvolvimento de habilidades amplas que poderiam ser mobilizadas em diferentes problemas e desafios.

Quando o ensino e a aprendizagem são restritos aos saberes declarativos ou conceituais, a formação para cidadania permanece deficiente, uma vez que requer uma abordagem equitativa dos três tipos de conteúdo: conceituais, procedimentais e atitudinais (COLL et al., 2000; POZO; CRESPO, 2009). Se a concepção da educação científica inclui a formação para ação cidadã, são necessárias estratégias didáticas que propiciem aos alunos saber lidar com informações incompletas disponíveis e saber mobilizar raciocínios complexos e transversais. Para o desenvolvimento de tais habilidades, os alunos precisariam vivenciar momentos de debates reais com a finalidade de aprender a respeitar a opinião do outro, entender a pluralidade de concepções que existe na sociedade para adquirir altruísmo e a sensibilização referentes ao convívio em sociedades exigir a ponderação de opinião e de valores, para que seja possível a tomada de decisão inclusiva, ética e justa.

Um pensamento complexo e transdisciplinar, que inclua conceitos biológicos, aspectos sociais, econômicos, políticos e éticos precisam ser incorporados às predileções da educação formal, visto que a educação de conteúdos fragmentados e compartimentalizados não permite a organização de informações simultâneas de diferentes áreas e impede a formação de uma opinião ponderada acerca de questões sociocientíficas. Atividades como a defendida no presente trabalho podem ser realizadas em uma ação conjunta de professores de áreas de Ciências 
Humanas e Ciências da Natureza, por exemplo, para que estejam inclusas perspectivas complementares aos debates.

Defendemos que sem informações acerca de aspectos científicos, sociais, econômicos, políticos e éticos dos transgênicos, dificilmente o público se sentirá estimulado a solicitar uma maior participação pública. Defendemos, também, que a sociedade brasileira poderia estar mais preparada para o diálogo em instâncias políticas para poder ser consultada quando os rumos da ciência e da tecnologia forem estabelecidos e apresentados. Para tanto, é necessário que nos espaços formais de ensino a cidadania seja "ensaiada" com problemas hipotéticos ou exercida com problemas locais que sejam reais. A atividade aqui defendida não é definida em detalhes no que diz respeito às regras e a intervenção do professor (ou professores) porque cada atividade pode ser adaptada para finalidades formativas específicas.

Vale ressaltar que a transgenia, assim como a Educação Ambiental é um conteúdo transversal, pois perpassa dimensões amplas de conteúdos de ensino. Educar estudantes acerca de transgênicos de forma a restringir a temática a conteúdos conceituais da área de genética é o mesmo que realizar Educação Ambiental restringindo o ensino aos conteúdos conceituais de ecologia. 


\title{
Transgenics, scientific literacy and citizenship
}

\begin{abstract}
With a view to training for citizen action, we consider that public participation in technoscientific discussions and in decision-making of local or global dimensions require civil society to have a minimum of scientific training that allows the understanding of problems and options. Thus, in this article, we elaborate considerations about the teaching about transgenics, which include propositions of debate sessions between students for application in formal spaces of High School. Because it is a proposal for activity in a formal teaching space, the purpose of the activity is the scientific literacy of the students, aiming at preparing for the scientific engagement that provides the perspective of dialogue between specialists and society.
\end{abstract}

KEYWORDS: Transgenic. Scientific literacy. Training for citizenship. Scientific engagement. 


\section{REFERÊNCIAS}

AULER, Décio; DELIZOICOV, Demétrio. Alfabetização científico-tecnológica para quê?. Ensaio Pesquisa em Educação em Ciências (Belo Horizonte), v. 3, n. 2, p. 122-134, dez. 2001.

BRASIL. Parâmetros curriculares nacionais: Introdução aos parâmetros curriculares nacionais, Secretaria de Educação Fundamental, Brasília: Ministério da Educação, 1997. 126p.

CÂMARA DOS DEPUTADOS, Aprovado projeto que dispensa símbolo da transgenia em rótulos de produtos, Câmara Notícias, 2015. Disponível em: < http://www2.camara.leg.br/camaranoticias/noticias/CONSUMIDOR/486822APROVADO-PROJETO-QUE-DISPENSA-SIMBOLO-DA-TRANSGENIA-EM-ROTULOSDE-PRODUTOS.html>. Acesso em: 20 jan. 2015

COLL, César; POZO, Juan Ignacio; SARABIA, Barnabé; VALLS, Enric. Os Conteúdos na reforma - ensino e aprendizagem de conceitos, procedimentos e atitudes. Porto Alegre: Artmed, 2000.

DELIZOICOV. Demétrio; ANGOTTI, José André Peres; PERNAMBUCO, Marta Maria. Ensino de Ciências: Fundamentos e Métodos. 4 ed. São Paulo: Cortez, 2011.

EUROPEAN COMMISSION. Science education for responsible citizenship. Report to the European Commission of the Expert Group on Science Education. Directorate-General for Research and Innovation, Science with and for Society, Brussels, $2015 . \quad$ Disponível em <http://ec.europa.eu/research/swafs/pdf/pub_science_education/KI-NA-26-893EN-N.pdf>. Acesso em: 12 jan. 2016.

EWEN, Stanley WB; PUSZTAI, Arpad. Effect of diets containing genetically modified potatoes expressing Galanthus nivalis lectin on rat small intestine. The Lancet, v. 354, n. 9187, p. 1353-1354, 1999.

FERREIRA, Heline Sivini. A ausência de participação pública nas decisões envolvendo organismos transgênicos: o sistema constitucional de responsabilidades compartilhadas em risco. Lusíada: Direito e Ambiente, n. 2-3, p. 121-144, 2015.

FIOCRUZ, Rotulagem de transgênicos como medida de saúde pública, Agência Fiocruz de Notícias, Rio de Janeiro, abr. 2015. Disponível em: $<$ http://agencia.fiocruz.br/rotulagem-de-transg\%C3\%AAnicos-como-medida-desa\%C3\%BAde-p\%C3\%BAblica>. Acesso em: 13 jan. 2016. 
FLECK, Ludwik. Gênese e desenvolvimento de um fato científico. Belo Horizonte: Fabrefactum Editora, 1986.

FURNIVAL, Ariadne Chloë; PINHEIRO, Sônia Maria. A percepção pública da informação sobre os potenciais riscos dos transgênicos na cadeia alimentar. História, ciências, saúde - Manguinhos, v. 15, n. 2, p. 277-291, jun. 2008.

GIDDENS, Anthony. Sociologia. Tradução Alexandra Figueiredo; Ana Patrícia Duarta Baltazar; Catarina Lorga da Silva; Patrícia Matos Vasco Gil. 6ed. Porto Alegre: Penso, 2012.

GUERRANTE, Rafaela Di Sabato. Transgênicos: uma visão estratégica. Rio de Janeiro: Editora Interciência, 2003.

GUIVANT, Julia S. Transgênicos e percepção pública da ciência no brasil, Ambiente \& Sociedade, v.9, n.01, p.81-105, 2006.

HEDGECOE, Adam M.; MARTIN, Paul A. Genomics, STS, and the Making of Sociotechnical Futures. In: HACKETT, Edward J. et al. The handbook of science and technology studies, 3 ed., London. England, Society for Social Studies of Science, 2007, p.817-840.

HOBAN, Thomas J. Public attitudes towards agricultural biotechnology. ESA Working Paper, n.04-09, 2004.

IDEC, Sociedade diz não ao fim da rotulagem de alimentos transgênicos, Instituto Brasileiro de Defesa do Consumidor, mai. 2015. Disponível em <http://www.idec.org.br/em-acao/em-foco/sociedade-diz-no-ao-fim-darotulagem-de-alimentos-transgenicos>. Acesso em: 18 jan. 2016.

IRWIN, Alan. Risk, science and public communication: Third order thinking about scientific culture. In: BUCCHI, Massimiano; TRENCH, Brian (edit). Public Communication of Science and Technology Handbook. London: Routledge, 2008, p.199-212.

JAMES, Clive. Global status of commercialized biotech/GM crops: 2013. ISAAA brief, v. 46, 2013.

JENSEN, Eric; BUCKLEY, Nicola. Why people attend science festivals: interests, motivations and self-reported benefits of public engagement with research. Public Understanding of Science, v. 23, n. 5, p. 557-573, 2014. 
KRASILCHIK, Myriam. O professor e o currículo das ciências. São Paulo: Editora Pedagógica e Universitária, 1987.

LAJOLO, Franco M.; NUTTI, Marília R. Transgênicos: bases científicas da sua segurança, São Paulo: Sociedade Brasileira de Alimentação e Nutrição, 2003.

NOVAS, Carlos.; ROSE, Nikolas. Genetic Risk and the Birth of the Somatic Individual, Economy and Society, v. 29, n. 4, p. 485-513, 2000.

PÉREZ, Leonardo Fabio Martínez; CARVALHO, Washington Luiz Pacheco de. Contribuições e dificuldades da abordagem de questões sociocientíficas na prática de professores de ciências. Educação e Pesquisa, v. 38, n. 3, p. 727-741, 2012.

PIACENTINI, Patricia. Proposta quer limitar informação nos rótulos. Ciência e Cultura, v. 67, n. 3, p. 12-13, 2015.

POZO, Juan Ignacio; CRESPO, Miguel Ángel Gómez. A aprendizagem e o ensino de ciências: do conhecimento cotidiano ao conhecimento científico. Porto Alegre: Artmed, 2009.

PRAIA, João; GIL-PÉREZ, Daniel; VILCHES, Amparo O papel da natureza da ciência na educação para a cidadania. Ciência \& Educação, v. 13, n. 2, p. 141-156, 2007.

PRIEST, Susanna. Critical science literacy: what citizens and journalists need to know to make sense of science. Bulletin of Science, Technology \& Society, v. 33, n.5-6, p. 138-145, 2013.

RATCLIFFE, Mary; GRACE, Marcus. Science education for citizenship: teaching socio-scientific issues. UK: McGraw-Hill Education, 2003.

REECE, Jane. et al. Biologia de Campbell, Porto Alegre, Artmed, 2015.

REIS, Pedro; GALVÃO, Cecília. Os professores de ciências naturais e a discussão de controvérsias sociocientifícas: dois casos distintos. Revista Electrónica de Enseñanza de la Ciencias, v. 7, n. 3, p. 746-772, 2008.

SANTOS, Wildson Luiz Pereira dos. Educação científica na perspectiva de letramento como prática social: funções, princípios e desafios, Revista Brasileira de Educação, v. 12, n. 36, p. 474-550, 2007. 
SARABIA, Barnabé. A Aprendizagem e Ensino das Atitudes. In: COLL, César et al. Os Conteúdos na reforma - ensino e aprendizagem de conceitos, procedimentos e atitudes. Porto Alegre: Artmed, 2000, p. 153-165.

SENADO FEDERAL (Brasil), Você está opinando sobre: Projeto de Lei da Câmara PLC 34/2015, e-Cidadania, 2015. Disponível em: <http://www12.senado.gov.br/ecidadania/visualizacaotexto?id=164869>. Acesso em: 15 fev. 2018

SOUSA, Cidoval Morais; BERBEL, Danilo Brancalhão; ROTHBERG, Danilo; HAYASHI, Maria Cristina Piumbato Innocentini. Comunicação da ciência, transgenia e estudos CTS: a contribuição da informação para o debate público. In: SOUSA, Cidoval Morais; HAYASHI, Maria Cristina Piumbato Innocentini; ROTHBERG, Danilo (orgs.). Apropriação social da ciência e da tecnologia: contribuições para uma agenda. Campina Grande: EDUEPB, 2011, p. 17-42.

SOUZA, Aline Furtuozo; FARIAS, Gilmar Bezerra. Percepção do conhecimento dos alunos do ensino médio sobre transgênicos: concepções que influenciam na tomada de decisões. Experiências em Ensino de Ciências. v. 6, n. 1, p. 21-32, 2011.

UNITED KINGDOM. Department of Trade and Industry. GM Nation? The findings of the public debate. London, 2003.

VASCONCELLOS, Celso dos Santos. Construção do conhecimento: em sala de aula. 13 ed. São Paulo: Libertad, 2002.

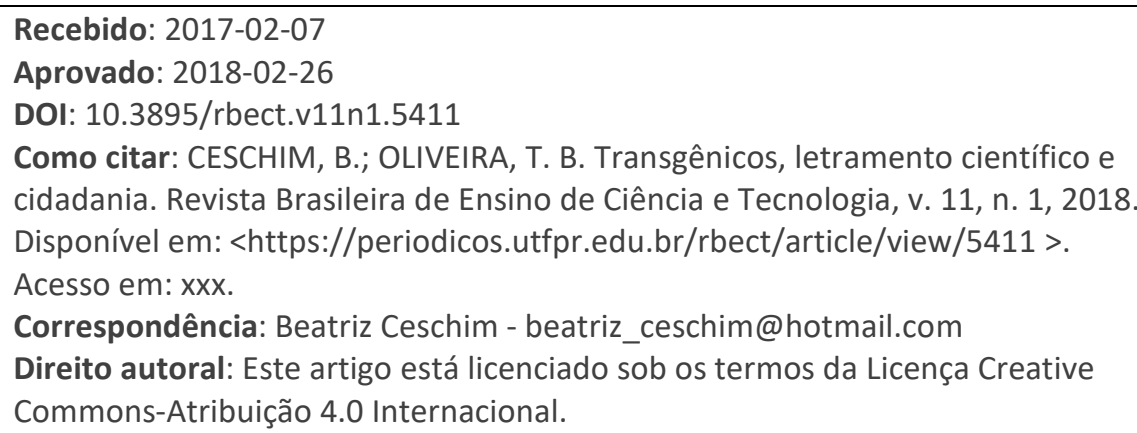

